\title{
Humic substances of differently matured composts produced from municipal solid wastes and biomass of energetic plants
}

\begin{abstract}
The aim of the study was to assess the transformation of humic substances during composting of biomass of energetic plants and municipal solid waste. The type of the organic material to be composted and the type of technology used affect the course of the humic substances transformation and formation of compost maturity parameters. Compost produced from the mixture of energetic willow and hay biomass contained humic substances with higher share of low-molecular fractions and lower share of humic acids in total organic carbon than those produced from municipal solid wastes. Obtained results also showed that insoluble alkali fraction plays an important role in humification process by its convertion to a new humic substances. Share of humic and fulvic fractions in relation to the total organic carbon appears to be reliable indicator of composting as a process of enhancing organic matter humification.
\end{abstract}

Keywords: compost, humic substances, maturity indexes

\section{INTRODUCTION}

In recent decades, a significant decrease in humus resources in agricultural soils has been observed, as a result of increased mineralization processes of organic matter, which are not balanced by appropriate organic fertilization (Zaujec 2007; Krasowicz et al. 2011; Weber et al. 2014; Gonet 2015). Its presence is a key element that plays an important role in the circulation of nutrients, which transforms into proper plant production and an appropriate quality of the environment. In 2001, the European Commission in the Sixth Community Environment Action Program adopted a thematic strategy in the field of soil protection, aimed at halting and reversing the processes of humus degradation, which may occur faster than the soil-forming and repair processes. In the communication "Towards a Thematic Strategy of Soil Protection" from 2002 (COM (2002) 179), among the eight main threats to soils in the EU, particular attention is paid to the decline in the content of soil organic matter. According to Gonet (2007), on the basis of the criteria in force in the international convention prepared in 2001 by the European Soil Bureau (ESB), in Poland $89 \%$ of agricultural land is characterized by low or very low content of organic carbon, which oscillates around $0 \div 2 \%$. The low fertility status of soils can be effectively modified by the use of organic fertilization (Baran et al. 1996; Jamroz and Drozd 1999; Leszczyńska and Kwiatkowska-Malina 2013). The increase in soil fertility and the improvement of its fertility may be influenced by the addition to soil in the form of peat, lignite, sewage sludge or compost (Baran et al. 1996). Styszko et al. (2017) showed that light soil fertilization with compost from municipal sediments increases the content of humus and organic carbon in soil, and also raises the soil $\mathrm{pH}$.

Poland, after entering the European Union, increased its share of heat and electricity using renewable energy sources, including energy willow due to the large amount of biomass. When the subsidy from EU funds for energy willow cultivation was limited and its cultivation from the producer's point of view became unprofitable, as, in addition, among Polish power companies there was increased interest in imported energy, which proved to be a cheaper alternative to willow produced by native producers. The collapse in demand for willow crops forced many farmers to liquidate the plantations, which in turn resulted in the problem of disposal of the produced material. On the other hand, in Europe there is a growing interest in using materials other than peat for horticultural substrates (Lazcano et al. 2009), as the consequence of exploiting peat deposits is a significant reduction in peatland areas in these countries, e.g. in Germany. In the Great Britain there is also a reduction in the proportion of peat in the substrate and its substitution with materials of other origin. This arouses increasing interest in finding new solutions in the field of horticultural substrates. One proposal may be the production of compost based on readily available plant materials, physicochemically 
appropriate, pathogen-free and environmentally friendly. Many studies confirm the possibility of using compost as substrates for vegetable crops without causing a negative impact on them or the environment (Waldron and Nichols 2009). Additionally, based on research, properly composted organic wastes are compatible with the requirements of peat substratum in potted plants (Morales-Corts et al. 2014). Due to the need to find new materials as horticultural substrates simultaneously with the large amounts of plant material remaining as a result of energy willow cultivation, the concept of the production of composts based on available biomass appeared.

The main goal of the composting process is to obtain a product that is fully mature, physically and chemically stabilized. Humic substances present in the mature compost are characterized by a high degree of stability, so that after being introduced into the soil they can effectively act as an additive improving its fertility and increasing the resources of organic carbon (Senesi and Brunetti 1996; Dziamski et al. 2005; Mielnik 2009; Zukowska et al. 2012; Dębska et al. 2016; Weber et al. 2018). They consist mainly of humic and fulvic acids and humins. In the composting process, i.e. transformations of organic matter, changes in the share of particular groups of organic carbon compounds are observed. In fully mature composts, the humification index based on the ratio of humic to fulvic acids $\left(\mathrm{C}_{\mathrm{HA}} / \mathrm{C}_{\mathrm{FA}}\right)$ usually assumes higher values as compared to immature composts (Chen et al. 1996, Tuomela et al. 2000). The direction of transformation of organic matter depends on the type of material undergoing the decomposition process.

The aim of the study was to assess the changes of humic substances during composting of biomass of energetic plants (WBC) and municipal solid waste from two different composting plants (MSWC and MSWC2) representing different composition and composting technology. The quality of composts was also evaluated using the maturity indexes calculated on the basis of the quantitative and qualitative composition of humus compounds. The main hypothesis were:

- humic substances content is changing during composting process in similar direction regardless of technology and type of organic material used,

- transformation of humic substances during composting process can be used as an index of compost maturity.

\section{MATERIALS AND METHODS}

The object of the research were composts (Table 1) produced from the mixture $(1: 1)$ of energetic
TABLE 1. Basic properties of matured composts obtained in the experiment

\begin{tabular}{lccc}
\hline Parameter & WBC & MSWC & MSWC2 \\
\hline TOC $\mathrm{g} \cdot \mathrm{kg}^{-1}[\mathrm{~d} . \mathrm{m}]$. & 351.0 & 173.4 & 87.8 \\
\hline $\mathrm{Nt} \mathrm{g} \cdot \mathrm{kg}^{-1}[\mathrm{~d} . \mathrm{m}]$. & 15.1 & 14.7 & 13.4 \\
\hline TOC:Nt $\mathrm{g} \cdot \mathrm{kg}^{-1}[\mathrm{~d} . \mathrm{m}]$. & 23.24 & 11.79 & 6.55 \\
\hline $\mathrm{pH}(\mathrm{KCl})$ & 5.7 & 6.1 & 6.2 \\
\hline
\end{tabular}

willow and hay biomass (WBC) - composting process was leading on a pile and compost made from unsorted municipal waste in the Katowice agglomeration (MSWC), which production is based on the DANO technology (Dziejowski and Kazanowska 2002). Detailed description can be found in the paper by Kałuża-Haładyn et al. (2018). The third analysed compost was produced from municipal waste originating from Zielona Góra (MSWC2). The production method was based on the use of the KKO-100 system (separation at source and on a manual sorting line, aerobic stabilisation in open chambers, and forced aeration of solid waste), whose main purpose is to stabilize waste through oxygen processes, which allows their safe storage and use in accordance with applicable regulations (Suchowska-Kisielewicz et al. 2017).

Samples taken from the piles in different phases of compost maturity were used for the study. Compost samples were collected as a collective sample taken from 5-6 places from each pile. WBC material was collected at 1, 37, 54, 71, 130, 167 days of composting (6 samples), compost from Katowice in 1, 7, 14, 30,90 and 180 days (6 samples), in turn material representative for Zielona Góra was taken at 1, 14, $28,45,56,70,90,107,127$ and 149 days (10 samples). After drying and grinding the collected material, a detailed analysis in the samples of compost in different maturity phases were made: total organic carbon (TOC) was analysed by the CS-mat 5500 analyzer (Strohlein GmbH \& Co., Kaarst, Germany, currently Bruker AXS Inc., Madison, WI, USA); humic substances were extracted according to the method recommended by the International Humic Substances Society (Stevenson 1994), separating fractions:

$-\mathrm{C}_{\mathrm{AC}}$ - fraction (containing mainly low molecular fulvic fraction) extracted by $0.05 \mathrm{M} \mathrm{HCl}$

- $\mathrm{C}_{\mathrm{ALC}}$ - fraction extracted by $0.1 \mathrm{M} \mathrm{NaOH}$; extraction was followed repeatedly as long as the solution were in light color

- $\mathrm{C}_{\mathrm{HA}}$ - carbon of humic acids

$-\mathrm{C}_{\mathrm{FA}}$ - carbon of fulvic acids

$-\mathrm{C}_{\mathrm{h}}$ - humins fraction, calculated according to the formula: $\mathrm{C}_{\mathrm{h}}=\mathrm{TOC}-\left(\mathrm{C}_{\mathrm{AC}}+\mathrm{C}_{\mathrm{ALC}}\right)$. 
On the base of result obtained maturity degree of the compost was determined. Maturity indexes were calculated based on the humic substances transformations (Adani et al. 1997, Drozd et al. 2003):

- $\mathrm{HR}_{1}=\mathrm{C}_{\mathrm{HA}} / \mathrm{C}_{\mathrm{FA}}-$ humification index presented direction of humification

- $\mathrm{HI}=\mathrm{C}_{\mathrm{AC}} / \mathrm{C}_{\mathrm{ALC}}$ - humification index presented share of low molecular fraction in relation to the alkali fraction

- $\mathrm{HR}_{2}=\left[\left(\mathrm{C}_{\mathrm{AC}}+\mathrm{C}_{\mathrm{ALC}}\right) / \mathrm{TOC}\right] \cdot 100$ - humification index, presented share of humic and fulvic fractions in relation to the total organic carbon

- $\mathrm{HR}_{3}=\mathrm{C}_{\mathrm{HA}} /\left(\mathrm{C}_{\mathrm{FA}}+\mathrm{C}_{\mathrm{AC}}\right)$ - humification index, presented share of humic acids in relation to the fulvic fraction

- $\mathrm{P}_{\mathrm{HA}}=\left(\mathrm{C}_{\mathrm{HA}} / \mathrm{C}_{\mathrm{ALC}}\right) \cdot 100$ - percentage share of humic acids in relation to the alkali fraction

- $\mathrm{P}_{\mathrm{FA}}=\left(\mathrm{C}_{\mathrm{FA}} / \mathrm{C}_{\mathrm{ALC}}\right) \cdot 100$ - percentage share of fulvic acids in relation to the alkali fraction.

Results were statistically verified using Statistica 13.

\section{RESULTS AND DISCUSSION}

The research carried out indicates that during the composting, quantitative and qualitative transformation of the organic matter occurred, as evidenced by the decreasing with different intensity depending on the composted material, the content of organic carbon (TOC) (Table 2). The most intense changes were observed at the time of the thermophilic phase, after which the mineralization processes were slowed down and stabilization marked. Raw compost from Zielona Góra contained the lowest value of 205.90 $\mathrm{g} \cdot \mathrm{kg}^{-1}$ of organic carbon (TOC), while the highest $408 \mathrm{~g} \cdot \mathrm{kg}^{-1}$ TOC had compost from energetic plants. Only in the compost from Zielona Góra there was over $50 \%$ of the TOC loss in relation to the initial value, which is the result of the technology used and the method of conducting the pile.

Along with the mineralization processes occurring during composting, simultaneous processes of humification of organic matter occur. For WBC, a gradual increase in $\mathrm{C}_{\mathrm{FA}}$ and $\mathrm{C}_{\mathrm{HA}}$ up to 54 days of composting to $8.41 \%$ of TOC can be observed. After this time there was a clear decrease of this fraction and another small increase finally assuming the value of $6.61 \%$ of TOC. Similar results were obtained by WójcikWojtkowiak (1976), who found that the humification of plant material mainly leads to the formation of fulvic acids. On the same day there was a significant increase in $\mathrm{C}_{\mathrm{AC}}$ from $7.11 \%$ of TOC to $15.68 \%$ TOC. The observed course of fractions formation is related to the type of waste subjected to composting processes and the thermophilic phase impact on a given type of waste.
TABLE 2. Fractional composition of humic substances in differently matured composts

\begin{tabular}{|c|c|c|c|c|c|c|}
\hline \multirow{2}{*}{$\begin{array}{l}\text { Compo- } \\
\text { sting } \\
\text { days } \\
\end{array}$} & TOC & $\mathrm{C}_{\mathrm{AC}}$ & $\mathrm{C}_{\mathrm{ALC}}$ & $\mathrm{C}_{\mathrm{HA}}$ & $\mathrm{C}_{\mathrm{FA}}$ & $\mathrm{C}_{\mathrm{h}}$ \\
\hline & $\mathrm{g} \cdot \mathrm{kg}^{-1}$ [d.m.] & \multicolumn{5}{|c|}{$\%$ of TOC } \\
\hline & \multicolumn{6}{|l|}{ WBC } \\
\hline 1 & 408.0 & 7.8 & 22.4 & 8.3 & 14.1 & 69.9 \\
\hline 37 & 403.0 & 8.7 & 23.4 & 8.5 & 14.9 & 67.9 \\
\hline 54 & 391.0 & 7.1 & 24.2 & 8.4 & 15.9 & 68.6 \\
\hline 71 & 375.0 & 15.7 & 24.6 & 4.3 & 20.3 & 59.7 \\
\hline 130 & 361.0 & 14.9 & 28.0 & 5.2 & 22.9 & 57.1 \\
\hline \multirow[t]{2}{*}{167} & 351.0 & 15.0 & 29.2 & 6.6 & 22.5 & 55.8 \\
\hline & \multicolumn{6}{|l|}{ MSWC } \\
\hline 1 & 242.8 & 17.7 & 37.9 & 14.0 & 23.9 & 44.4 \\
\hline 7 & 235.1 & 12.3 & 40.8 & 15.3 & 25.5 & 46.8 \\
\hline 14 & 227.3 & 12.3 & 44.9 & 26.4 & 18.5 & 42.8 \\
\hline 30 & 207.5 & 8.7 & 54.0 & 31.3 & 22.7 & 37.4 \\
\hline 90 & 181.0 & 8.8 & 59.7 & 47.5 & 12.2 & 31.5 \\
\hline \multirow[t]{2}{*}{180} & 173.4 & 8.7 & 59.4 & 31.1 & 28.3 & 32.0 \\
\hline & \multicolumn{6}{|l|}{ MSWC2 } \\
\hline 1 & 205.9 & 5.2 & 9.2 & 4.2 & 4.9 & 85.7 \\
\hline 14 & 183.9 & 6.2 & 11.1 & 5.1 & 6.0 & 82.7 \\
\hline 28 & 155.5 & 8.8 & 13.8 & 5.6 & 8.1 & 77.5 \\
\hline 45 & 135.8 & 11.3 & 20.2 & 9.3 & 10.9 & 68.6 \\
\hline 56 & 126.1 & 13.1 & 22.2 & 10.5 & 11.7 & 64.6 \\
\hline 70 & 116.4 & 10.7 & 23.0 & 10.6 & 12.4 & 66.4 \\
\hline 90 & 106.8 & 9.4 & 23.5 & 12.3 & 11.1 & 67.2 \\
\hline 107 & 99.1 & 9.3 & 25.4 & 13.5 & 11.9 & 65.3 \\
\hline 127 & 92.8 & 8.6 & 25.8 & 14.4 & 11.4 & 65.6 \\
\hline 149 & 87.8 & 7.8 & 25.9 & 14.7 & 11.2 & 66.4 \\
\hline
\end{tabular}

A slightly different course of the $\mathrm{C}_{\mathrm{HA}}$ and $\mathrm{C}_{\mathrm{FA}}$ fractions can be noticed during composting of municipal waste. Despite the general upward trend in the content of fulvic and humic acids, the dynamics of the changes were different for individual composts. At the time of composting the MSWC, after 7 days of composting, there was a significant increase in $\mathrm{C}_{\mathrm{HA}}$ share from $15.31 \%$ of TOC to $26.40 \%$ of TOC. At the same time there were fluctuations in CFA values, which could have been caused by insufficient aeration of the prism, which in turn favored the course of anaerobic processes that could significantly modify the synthesis of humic compounds. In the case of Zielona Góra, the highest percentage of $\mathrm{C}_{\mathrm{HA}}$ and $\mathrm{C}_{\mathrm{FA}}$ share was found in the final composting process, i.e. after 149 days. The $\mathrm{C}_{\mathrm{HA}}$ value increased from $4.22 \%$ TOC to $14.68 \%$ TOC, representing $56.75 \% \mathrm{C}_{\mathrm{ALC}}$, and $\mathrm{C}_{\mathrm{FA}}$ from $4.95 \%$ TOC to $11.18 \%$ TOC, representing $43.21 \% \mathrm{C}_{\mathrm{ALC}}$. The course of the formation of fulvic and humic acids for the MSWC and MSWC2 is in line with the conclusions of Singh and Amberger (1990), according to which in the initial phase of the 
composting process fulvic acids predominate over the humic ones, after which time the proportions change in favor of humic acids.

Humins fraction $\left(\mathrm{C}_{\mathrm{h}}\right)$ contains organic substances that have not been dissolved in the solutions during the extraction with various reagents. It is widely believed that it can be a potential source of energy and carbon for microorganisms involved in composting. In the composts analyzed over time, regardless of the substrate subjected to composting, a systematic decrease in the content of the $\mathrm{C}_{h}$ fraction was observed, but the dynamics of these changes were different in the examined objects. The decreasing tendency testifies to the occurrence of partially undefined and non- humified organic residues and demonstrates the proper course of the composting process.

The highest $\mathrm{C}_{h}$ share in the first days of composting were recorded for WBC (69.85\% of TOC) and for MSWC2 (85.67\% of TOC), while for MSWC the highest share of this fraction was achieved after 7 days and amounted to $46.83 \%$ of TOC. The percentage of non-hydrolyzing carbon for WBC and MSWC2 was over $50 \%$ of TOC during the entire composting process, according to Beffa et al. (1996), Chen et al. (1997) and Siuta (1999) this may indicate the heterogeneous character of waste and the large share of various types of organic compounds.

The value of HI during the composting of waste of various composition was differentiated depending on the type of material tested. Humification indices (HI), recognized by many authors (De Nobili and Petruzzi 1988; Jimenez and Garcia 1992; Adani et al. 1997) as one of the most important compost maturity indicators, one can notice that their stabilization took place at the end of the thermophilic phase. For WBC it occurred after 71 days, for MSWC after 30 days and for MSWC2 after 70 days of composting (Table 3). HI value indicated a fairly high degree of humification of organic matter indicating the $\mathrm{C}_{\mathrm{ALC}}$ dominance which is particularly evident for MSWC and MSCW2, unlike WBC, where the increasing content of both $\mathrm{C}_{\mathrm{AC}}$ and $\mathrm{C}_{\mathrm{ALC}}$ fraction, determined by waste composition, influenced on the different direction of HI formation. Obtained results also showed that low molecular organic compounds play more important role in humification during composting of biomass of energetic plants than during composting of municipal solid wastes (Drozd et al. 2003) (Table 2 and 3). Comparying three types of composting it can be concluded that the most effective, from the "humification" point of view, is MSWC2 and KKO-100 system which leads to obtain organic matter with the highest portion of "core humic substances" during the process.
Table 3 presents the remaining humification indexes, including HR1, whose successive increase characteristic of MSWC and MSWC2 with simultaneous increase in CHA content indicates an increase in polymerisation of humus compounds (Jiménez and Garcia 1992). During composting of the WBC, $\mathrm{HR}_{1}$ was decreasing although other parameters $\left(\mathrm{HR}_{2}, \mathrm{C}_{\mathrm{h}}\right)$ showed proper direction of organic matter transformation, so in this case HR1 index does not reflect degree of maturity, as other authors believe (Chen et al. 1996; Tuomela et al. 2000).

TABLE 3. Maturity indices of composted municipal solid wastes and biomass of energetic plants

\begin{tabular}{|c|c|c|c|c|c|c|}
\hline $\begin{array}{l}\text { Compo- } \\
\text { sting } \\
\text { days } \\
\end{array}$ & $\mathrm{HI}$ & $\mathrm{HR}_{1}$ & $\mathrm{HR}_{2}$ & $\mathrm{HR}_{3}$ & $\mathrm{P}_{\mathrm{HA}}$ & $\mathrm{P}_{\mathrm{FA}}$ \\
\hline \multicolumn{7}{|c|}{ WBC } \\
\hline 1 & 0.35 & 0.58 & 30.2 & 0.38 & 36.9 & 63.1 \\
\hline 37 & 0.37 & 0.57 & 32.1 & 0.36 & 36.5 & 63.5 \\
\hline 54 & 0.29 & 0.53 & 31.4 & 0.37 & 34.7 & 65.4 \\
\hline 71 & 0.64 & 0.21 & 40.3 & 0.12 & 17.5 & 82.5 \\
\hline 130 & 0.53 & 0.23 & 42.9 & 0.14 & 18.5 & 81.5 \\
\hline 167 & 0.52 & 0.29 & 44.2 & 0.18 & 22.7 & 77.3 \\
\hline \multicolumn{7}{|c|}{ MSWC } \\
\hline 1 & 0.47 & 0.59 & 55.6 & 0.34 & 37.0 & 63.0 \\
\hline 7 & 0.30 & 0.60 & 53.2 & 0.40 & 37.5 & 62.5 \\
\hline 14 & 0.27 & 1.43 & 57.2 & 0.86 & 58.8 & 41.2 \\
\hline 30 & 0.16 & 1.38 & 62.7 & 1.00 & 58.0 & 42.0 \\
\hline 90 & 0.15 & 3.91 & 68.5 & 2.26 & 79.6 & 20.4 \\
\hline 180 & 0.15 & 1.10 & 68.1 & 0.84 & 52.4 & 47.6 \\
\hline \multicolumn{7}{|c|}{ MSWC2 } \\
\hline 1 & 0.56 & 0.85 & 14.3 & 0.42 & 46.0 & 54.0 \\
\hline 14 & 0.56 & 0.85 & 17.3 & 0.42 & 46.0 & 54.0 \\
\hline 28 & 0.64 & 0.69 & 22.6 & 0.33 & 40.8 & 59.2 \\
\hline 45 & 0.56 & 0.85 & 31.4 & 0.42 & 46.0 & 54.0 \\
\hline 56 & 0.59 & 0.89 & 35.4 & 0.42 & 47.2 & 52.8 \\
\hline 70 & 0.47 & 0.85 & 33.7 & 0.46 & 46.0 & 54.0 \\
\hline 90 & 0.40 & 1.10 & 32.8 & 0.60 & 52.5 & 47.5 \\
\hline 107 & 0.36 & 1.13 & 34.7 & 0.64 & 53.1 & 46.9 \\
\hline 127 & 0.33 & 1.26 & 34.4 & 0.72 & 55.8 & 44.2 \\
\hline 149 & 0.30 & 1.31 & 33.6 & 0.77 & 56.8 & 43.2 \\
\hline
\end{tabular}

According to Drozd et al. (2003) the course of changes in $\mathrm{HR}_{2}$ index point to composting as a process of enhancing organic matter humification.

Analyzing the indicators of $\mathrm{HR}_{2}, \mathrm{HR}_{3}$ and $\mathrm{P}_{\mathrm{HA}}$ and $\mathrm{P}_{\mathrm{FA}}$, it can be concluded that the humification process is the most marked in the final stages of the thermophilic phase.

Table 4 presents significant correlations for individual fractions and indices of maturity characteristic 
TABLE 4. Correlation coefficients between composting days and humification parameters during composting process

\begin{tabular}{|c|c|c|c|}
\hline & WBC & MSWC & MSWC2 \\
\hline & \multicolumn{3}{|c|}{ Composting days } \\
\hline TOC & $-0.97 *$ & $-0.91 *$ & $-0.94 *$ \\
\hline $\mathrm{C}_{\mathrm{AC}}$ & 0.78 & -0.64 & 0.21 \\
\hline $\mathrm{C}_{\mathrm{ALC}}$ & $0.99 *$ & $0.82 *$ & $0.91 *$ \\
\hline $\mathrm{C}_{\mathrm{HA}}$ & -0.55 & 0.56 & $0.97 *$ \\
\hline $\mathrm{C}_{\mathrm{FA}}$ & $0.93 *$ & 0.15 & $0.74 *$ \\
\hline $\mathrm{C}_{\mathrm{h}}$ & $-0.92 *$ & $-0.84 *$ & $-0.79 *$ \\
\hline $\mathrm{HI}$ & 0.59 & -0.67 & $-0.92 *$ \\
\hline $\mathrm{HR}_{1}$ & -0.76 & 0.31 & $0.91 *$ \\
\hline $\mathrm{HR}_{2}$ & $0.92 *$ & $0.84 *$ & $0.79 *$ \\
\hline $\mathrm{HR}_{3}$ & -0.75 & 0.39 & $0.93 *$ \\
\hline $\mathrm{P}_{\mathrm{HA}}$ & -0.74 & 0.38 & $0.89 *$ \\
\hline$\underline{\mathrm{P}_{\mathrm{FA}}}$ & 0.74 & -0.38 & $-0.89 *$ \\
\hline
\end{tabular}

for the composts tested, depending on the time of composting. Based on the calculated correlation coefficients, it was found that with the time of the composting process, the content of organic carbon and the humin fraction significantly decreased. The data suggest that one of the possible pathway is biodegradation and conversion to a new humic substances. A significant positive correlation with the composting time occurred in all variants with reference to $\mathrm{C}_{\mathrm{ALC}}$ and the humification index seems to be in a good agreement with this theory. According to Genevini et al. (2003) humin fraction plays an important role in the humitication process by its solubilization to new humic substances and partial degradation of the soluble product. It remains an open question in which direction the conversion proceeds. Taking account to the result obtained it probably depends on the type of organic material to be composted. Regardless of the type of organic material to be composted obtained results confirmed that $\mathrm{HR}_{2}$ appears to be reliable indicator of composting as a process of mobilizing organic matter humification.

\section{CONCLUSIONS}

1. The type of the organic material to be composted and the type of technology used affect the course of the humic substances transformation and formation of compost maturity parameters. Composting the mixture of energetic willow and hay biomass leads to form humic substances with higher share of lowmolecular fractions and lower share of humic acids in total organic carbon in comparison to the transforming process of municipal solid wastes.
2. Regadless of the type of organic material composted the reduce the share of $\mathrm{C}_{h}$ fraction in TOC data in humin fraction content during the process suggest that the insoluble alkali fraction plays an important role in humification process by its convertion to a new humic substances.

3. $\mathrm{HR}_{2}$ appears to be reliable indicator of composting as a process of enhancing organic matter humification.

\section{ACKNOWLEDGEMENTS}

The study was partially financed by the Wroclaw University of Environmental and Life Sciences, grant no. B030/0021/18.

\section{REFERENCES}

Adani F., Genevini P.L., Gasperi F., Zorzi G., 1997. Organic matter evolution index (OMEI) as a measure of composting efficiency. Compost Science and Utilization 5(2): 53-62.

Baran S., Domżał H., Słowińska-Jurkiewicz A., Kwiecień J., Prangal J., 1996. Wpływ osadu ściekowego na wodno-powietrzne właściwości gleby piaszczystej. Zeszyty Problemowe Postępów Nauk Rolniczych 437: 53-60.

Beffa T., Blanc M., Marilley L., Frischer J.L., Lyon F., Arago M., 1996. Taxonomic and Metabolic Microbial Diversity During Composting. [In:] The Science of Composting (Bertoldi M., Sequi P., Lemmes B., Papi T. Editors). Blackie Academic \& Proffesional, London, Glasgow, Wienheim, New York, Tokyo, Melbourne, Madras: 149-161.

Chen Y., Chefetz B., Hadar Y., 1996. Formation and properties of humic substance originating from compost. [In:] The Science of Composting (Bertoldi M., Sequi P., Lemmes B., Papi T., Editors). Blackie Academic \& Professional, England: 382-393.

Chen Y., Chefetz B., Adani F., Genevini P., Hadar Y., 1997. Organic matter transformation during composting of Municipal Solid Waste. [In:] The Role Of Humic Substances in Ecosystems and in Environmental Protection (Drozd J., Gonet S.S., Senesi N., Weber J., Editors). Polskie Towarzystwo Substancji Humusowych, Wrocław: 795-804.

COM (2002) 179, final. Brussels. Communication for the Commission to the Council, the European Parliament, the Economic and Social Committee and the Committee of the Regions -Towards a Thematic Strategy for Soil Protection.

De Nobili M., Petruzzi F., 1988. Humification index (HI) as evaluation of the stabilization degree during composting. Journal of Environmental Technology 66, 5: 557-583.

Dębska B., Długosz J., Piotrowska-Długosz A., Banach-Szott M., 2016. The impact of a bio-fertilizer on the soil organic matter status and carbon sequestration - results from a fieldscale study. Journal of Soils and Sediments 16: 2335-2343.

Drozd J., Licznar M., Jamroz E., Bekier J., 2003. Próchniczne indeksy dojrzałości kompostów. [In:] Substancje humusowe w glebach i nawozach (Dębska B., Gonet S.S., Editors). Polskie Towarzystwo Substancji Humusowych, Wrocław: 75-94.

Dziamski A., Gonet S.S., Dębska B., 2005. Properties of humus in relation to soil particle size fraction. Earth and Environmental Sciences. Scientific papers University of Latvia, Vol. 692: 29-37.

Dziejowski J.E., Kazanowska J., 2002. Heat production during thermophyllic decomposition of municipals wastes in the 
Dano - system composting plant. [In:] Microbiology of composting (Insam H., Riddech N., Klammer S., Editors). Springer-Verlag, Berlin-Heidelberg: pp. 636.

Genevini P.L., Tambone F., Adani F., Veeken H.M., Nierop K.G.J., Montoneri E., 2003. Evolution and qualitative modifications of humin-like matter during high rate composting of pig faeces amended with wheat straw. Soil Science and Plant Nutrition. 49(6): 785-792.

Gonet S.S., 2007. Ochrona zasobów materii organicznej gleb, [In:] Rola materii organicznej w środowisku (Gonet S.S., Markiewicz M., Editors). Polskie Towarzystwo Substancji Humusowych, Wrocław: 7-29.

Gonet S., Smal H., Chojnicki J., 2015. Właściwości chemiczne gleb. Gleboznawstwo, Polskie Wydawnictwo Naukowe, Warszawa: 189-200.

Jamroz E., Drozd J., 1999. Influence of applying compost from municipal wastes on some physical properties of the soil. International Agrophysics 13(2): 167-170.

Jimenez E., Garcia V., 1992. Determination of maturity indices for city refuse composts. Agriculture and Environmental 38: 331-343.

Kałuża-Haładyn A., Jamroz E., Bekier J., 2018. The dynamics of some physical and physico-chemical properties during composting of municipal solid wastes and biomass of energetic plants. Soil Science Annual 69: 155-159.

Krasowicz S., Oleszek W., Horabik J., Dębicki R., Jankowiak J., Stuczyński T, Jadczyszyn J. 2011. Racjonalne gospodarowanie środowiskiem glebowym Polski. Polish Journal of Agronomy 7: 43-58.

Lazcano C., Arnold J., Tato A., Zaller J.G., Dominguez J., 2009. Compost and vermicompost as nursery pot components: effects on tomato plant growth and morphology. Spanish Journal of Agricultural Research 7(4): 944-951.

Leszczyńska D., Kwiatkowska-Malina J., 2013. The influence of organic matter on yield and quality of winter wheat Triticum aestivum ssp. Vulgare (1.) cultivated on soils contaminated with heavy metals. Ecological Chemistry and Engineering Society 20(4): 701-708.

Mielnik L., 2009. The application of photoinduced luminescence in research on humic substances of various origins. Oceanological and Hydrobiological Studies 38(3): 61-67.

Morales-Corts M.R., Gómez-Sánchez M.Á., Pérez-Sánchez R., 2014. Evaluation of green/pruning wastes compost and vermicompost, slumgum compost, and their mixes as growing media for horticultural production. Scientia Horticulturae 172: 155-60.
Senesi N., Brunetti G., 1996. Chemical and physico-chemical parameters for quality evaluation of humic substances produced during composting. [In:] The Science of Composting (Bertoldi M.D., Sequi P., Lemmes B., Papi T., Editors). Chapman \& Hall, London, United Kingdom: 195-212 pp.

Singh C.P., Amberger A., 1990. Humic substances in straw compost with rock phosphate. Biological Wastes, 31: 165-174.

Siuta J., 1999. Kompostowanie i wartości użytkowe kompostu, [In:] Kompostowanie i użytkowanie kompostu (Siuta J., Wasiak G., Editors). Wydawnictwo Eko-inżynieria, PuławyWarszawa: 7-20.

Stevenson F.J., 1994. Humus Chemistry: Genesis, Composition, Reactions (second ed.), John Wiley \& Sons, New York.

Styszko L., Fijałkowska D., Dąbrowski J., 2017. Wpływ nawożenia kompostem z osadów komunalnych na jakość gleby lekkiej pod uprawą wierzby wiciowej w czteroletnim cyklu uprawy. Rocznik Ochrona Środowiska 19: 618-32.

Suchowska-Kisielewicz M., Sadecka Z., Myszograj M., Płuciennik E., 2017. Mechanical-biological treatmentof municipal solid waste in Poland - case studies. Environmental Engineering and Management Journal 16(2): 481-491.

Tuomela M., Vikman M., Hatakka A., Itavaara M., 2000. Biodegradation of lignin in a compost environment: a review. Bioresource Technology 72: 169-183.

Waldron K.W., Nichols E., 2009. Composting of food-chain waste for agricultural and horticultural use. [In:] Handbook of Waste Management and Co-Product Recovery in Food Processing (Waldron K., Editor). Woodhead Publishing, pp. 680. Weber J., Chen Y., Jamroz E., Miano T., 2018. Preface: humic substances in the environment. Journal of Soils and Sediments 18(8): 2665-2667.

Weber J., Kocowicz A., Bekier J., Jamroz E., Tyszka R., Dębicka M., Parylak D., Kordas L., 2014. The effect of a sandy soil amendment with municipal solid waste (MSW) compost on nitrogen uptake efficiency by plants. European Journal of Agronomy 54: 54-60.

Wójcik-Witkowiak D., 1976. Przemiany związków azotowych znakowanych $15 \mathrm{~N}$ podczas humifikacji słomy w glebie. Roczniki Akademii Rolniczej, Poznań: Rozprawy 64.

Zaujec A., 2007. Funkcje materii organicznej w obiegu związków węgla i żyzności gleby. [In:] Rola materii organicznej w środowisku (Gonet S.S., Markiewicz M., Editors). Polskie Towarzystwo Substancji Humusowych, Wrocław: 31-46.

Zukowska G., Baran S., Wojcikowska-Kapusta A., 2012. The organic carbon content and fractional composition of organic matter in a ground reclaimed with sewage sludge. Przemysł Chemiczny 91(6): 1267-1269.

Received: May 1, 2019

Accepted: September 30, 2019

Associated editor: S. Gonet

\section{Substancje humusowe kompostów o różnym stopniu dojrzalości, produkowanych ze stałych odpadów miejskich i biomasy roślin energetycznych}

Streszczenie: Celem pracy była ocena transformacji substancji humusowych podczas kompostowania biomasy roślin energetycznych i stałych odpadów komunalnych. Rodzaj materiału organicznego, który poddany jest kompostowaniu oraz rodzaj zastosowanej technologii wpływają na przebieg transformacji substancji humusowych i tworzenie parametrów dojrzałości kompostu. Kompost wytworzony z mieszaniny biomasy wierzby energetycznej i siana zawierał substancje humusowe o wyższym udziale frakcji niskocząsteczkowych i niższym udziale kwasów huminowych w całkowitym węglu organicznym, w porównaniu do kompostu ze stałych odpadów miejskich. Uzyskane wyniki wykazały również, że nierozpuszczalna frakcja alkaliczna odgrywa ważną rolę w procesie humifikacji poprzez jej przekształcenie w nowe substancje humusowe. Indeks kierunku humifikacji wydaje się być wiarygodnym wskaźnikiem kompostowania, jako procesu indukującego humifikację materii organicznej.

Słowa kluczowe: kompost, substancje humusowe, indeksy dojrzałości 